\title{
A study of fetomaternal outcome in singleton pregnancies with cord around neck
}

\author{
Ankita Gahlot, Jyotsna Vyas*, Sunita Himani, Ekta
}

Department of Obstetrics and Gynecology, SMS Medical College Jaipur, Rajasthan, India

Received: 04 May 2021

Revised: 02 June 2021

Accepted: 03 June 2021

\section{*Correspondence:}

Dr. Jyotsna Vyas,

E-mail: drjyotsnavyas@gmail.com

Copyright: (c) the author(s), publisher and licensee Medip Academy. This is an open-access article distributed under the terms of the Creative Commons Attribution Non-Commercial License, which permits unrestricted non-commercial use, distribution, and reproduction in any medium, provided the original work is properly cited.

\section{ABSTRACT}

Background: Entanglement of umbilical cord around the foetal neck is a common finding at ultrasonography. A nuchal cord occurs when the umbilical cord becomes wrapped around the foetal neck by $360^{\circ}$. Nuchal cord is very common, with the prevalence rates of 6-37\%. Up to half of nuchal cords resolve before delivery.

Methods: This study was conducted on 100 women irrespective of parity with healthy singleton term pregnancies with cephalic presentation in the department of obstetrics and gynaecology, SMS Medical College Jaipur. They were included in study after applying inclusion criteria and a written informed consent was taken. Strict fetomaternal monitoring was done during labour and data was interpreted in terms of percentage.

Results: Out of 100 cases $71 \%$ delivered vaginally, $29 \%$ underwent caesarean section. None of the caesarean was done for cord around neck as the only indication. The indications for caesarean section were previous caesarean (34.4\%), preeclampsia (13.7\%), severe oligohydramnios (31\%) and non-reassuring foetal heart rate (20\%). Among the women who delivered normally, $53 \%$ had single loop, $29.5 \%$ had two loops, $14 \%$ had three loops and $2 \%$ had more than 3 loops. Among women who underwent caesarean section, $65 \%$ had single loop, $31 \%$ had two loops and $14 \%$ had more than two loops. Regarding neonatal outcome $9 \%$ neonates were admitted in NICU for reasons like meconium aspiration $(33.3 \%)$, preterm $(44 \%)$ and preeclampsia $(22 \%)$.

Conclusions: Cord around neck per se is not an indication for caesarean section and these cases can be delivered vaginally if careful intrapartum monitoring is done.

Keywords: Nuchal, Oligohydramnios, Preelampsia, Preterm

\section{INTRODUCTION}

A nuchal cord occurs when the umbilical cord becomes wrapped around the fetal neck 360 degrees. ${ }^{1}$ Nuchal cords are common finding at ultrasonography, with prevalence rates of $6 \%$ to $37 \%$. Up to half of nuchal cords resolve before delivery. ${ }^{2}$

The umbilical cord is a narrow tube-like structure that connects the developing baby to the placenta. The cord is sometimes called the baby's 'supply line' because it carries the baby's blood back and forth, between the baby and the placenta. It delivers nutrients and oxygen to the baby and removes the baby's waste products. The umbilical cord begins to form at 5 weeks after conception. It becomes progressively longer until 28 weeks of pregnancy, reaching an average length of 22-24 inches. $^{3}$ As the cord gets longer, it generally coils around itself.

The main cause for cord around fetal neck is excessive fetal movement. Other causes include an abnormally long cord, a weak cord structure, excessive amniotic fluid or having twins or multiple pregnancies. Long umbilical cords ( $>70 \mathrm{~cm}, 4 \%$ of cords) are documented to be directly associated with poor foetal outcome and associated with other umbilical cord accident, especially foetal 
entanglement, true knots (sometimes multiple) and torsion. The types of cord according to Giacomello classification includes: type A- nuchal cord that encircles the neck in a freely sliding pattern. This loop can undo itself. Type Bnuchal cord that encircles neck in a locked pattern and cannot undo itself. ${ }^{4}$

Ultrasound diagnosis of nuchal cord is done by nuchal skin indentation on grey scale and color Doppler studies. ${ }^{5}$ But it is not very sensitive and specific for diagnosing nuchal cord.

Most are not associated with perinatal morbidity and mortality. In some fetuses and newborns CAN may cause problems, especially when the cord is tightly wrapped around the neck. The cluster of cardiorespiratory and neurological signs and symptoms associated with unique physical features that occur secondary to tight cord-roundthe-neck has been referred to as 'tCAN syndrome' (tight cord around the neck syndrome). ${ }^{6}$ To alleviate fear in general population regarding adverse pregnancy and neonatal outcome this study was carried out to show that such natural occurrence does not have significant effect on pregnancy, labour and neonates if proper intra-partum foetal heart rate (FHR) monitoring could be provided by a caregiver.

Aim was to assess fetomaternal outcome in singleton pregnancies in sonographically proven cord around neck.

\section{METHODS}

It was a Hospital based observational study which was conducted in department of obstetrics and gynaecology SMS Medical College Jaipur from May 2020 to November 2020 on women with singleton pregnancies with sonographically proven cord around neck attending antenatal clinic. 100 patients after applying inclusion and exclusion criteria were included in the study.

\section{Inclusion criteria}

Singleton viable pregnancies, sonographically proven cord around neck, cephalic presentation with spontaneous onset of labour pain with intact membranes.

\section{Exclusion criteria}

Women with medical cormorbidities like cardiac disease, asthma, diabetes, renal disorder, thyrotoxicosis, premature rupture of membranes and post-dated pregnancy.

All eligible patients fulfilling inclusion criteria and exclusion criteria were enrolled. Written informed consent and history was taken. Detailed obstetrical examination for fundal height, fetal heart sound, lie and presentation was done. Bishop score was calculated and adequacy of pelvis was checked. All base line investigations including blood group and Rhesus factor, complete blood and urine examination, viral markers and blood glucose level were done. Ultrasound findings including gestational age, amount of liquor, number of loops were noted. Colour Doppler was done. Strict fetal monitoring (intrapartum cardiotocography (CTG), intermittent auscultation of fetal heart) with fetoscope was done after every 15 minutes in first stage of labour and after every contraction in second stage of labour. Any high risk factor was noted and mode of delivery was decided. Fetal outcome was assessed based on APGAR at 1 min and 5 minutes and NICU admission. Data collected was subjected to statistical analysis. The IBM SPSS statistics version 19 program was used for statistical analyses. Ethical approval was acquired by the ethical committee SMS medical college.

\section{RESULTS}

In our study we found that incidence of cord around neck was $42 \%$ in primigravida and $58 \%$ in multigravida. $36.2 \%$ multigravida were in the age group of 30-35 years while $40.4 \%$ primigravida were in the age group of $20-25$ years (Table 1).

Table 1: Distribution of cases according to parity.

\begin{tabular}{|lll|}
\hline & Primi para & Multipara \\
\hline $\mathbf{2 5}$ & 24 & 13 \\
\hline $\mathbf{2 5} \mathbf{- 3 0}$ & 15 & 18 \\
\hline $\mathbf{3 0 - 3 5}$ & 2 & 21 \\
\hline$>\mathbf{3 5}$ & 1 & 6 \\
\hline
\end{tabular}

Table 2: Distribution of cases according to number of loops and gestational age at delivery.

\begin{tabular}{|llll|l|}
\begin{tabular}{|l} 
No. of \\
loops
\end{tabular} & $\begin{array}{l}\text { Pre-term } \\
(<37 \text { weeks } \\
\text { GA) }\end{array}$ & $\begin{array}{l}\text { Term }(\mathbf{3 7}-\text { Post-term } \\
\mathbf{4 2} \text { weeks } \\
\text { GA) }\end{array}$ & $\begin{array}{l}\text { (>42 weeks } \\
\text { GA) }\end{array}$ & Total \\
\hline $\mathbf{1}$ & 18 & 33 & 6 & 57 \\
\hline $\mathbf{2}$ & 3 & 22 & 5 & 30 \\
\hline $\mathbf{3}$ & 1 & 5 & 3 & 9 \\
\hline $\mathbf{3}$ & 1 & 2 & 1 & 4 \\
\hline Total & 23 & 62 & 15 & 100 \\
\hline
\end{tabular}

Table 3: Cord length according to number of loops of cord around neck.

\begin{tabular}{|lllll|}
\hline $\begin{array}{l}\text { No. of } \\
\text { loops }\end{array}$ & $\begin{array}{l}\text { Cord } \\
\text { length } \\
(<40 \mathrm{~cm})\end{array}$ & $\mathbf{4 0 - 6 0} \mathrm{cm}$ & $\mathbf{> 6 0} \mathrm{cm}$ & Total \\
\hline $\mathbf{1}$ & $12(21 \%)$ & $37(65 \%)$ & $8(14 \%)$ & 57 \\
\hline $\mathbf{2}$ & $4(13 \%)$ & $11(36.6)$ & $15(50 \%)$ & 30 \\
\hline $\mathbf{3}$ & 0 & $5(38.4 \%)$ & $8(61.5 \%)$ & 13 \\
\hline & & & & 100 \\
\hline
\end{tabular}

Also in study $57 \%$ cases had single loop of cord around neck, 30\% had 2 loops, 9\% had 3 loops and 4\% had more than 3 loops of cord around neck.62\% cases with cord around neck were delivered at term, $15 \%$ were post term while $23 \%$ delivered before term (Table 2). Cord length increases as number of loops of cord around neck increases 
(Table 3). It was found that out of 100 cases, $71 \%$ delivered vaginally and $29 \%$ underwent cesarean section. (Table 4).

Table 4: Distribution according to the mode of delivery.

\begin{tabular}{|lllll|}
\hline & $\begin{array}{l}\text { Single } \\
\text { loop }\end{array}$ & 2 loops & $\begin{array}{l}>2 \\
\text { loops }\end{array}$ & Total \\
\hline Vaginal & $38(53.5 \%)$ & $21(29.5 \%)$ & $\begin{array}{l}12 \\
(16.9 \%)\end{array}$ & 71 \\
\hline Cesarean & $19(65.5 \%)$ & $9(31 \%)$ & $1(3.4 \%)$ & 29 \\
\hline Total & 57 & 30 & 13 & 100 \\
\hline
\end{tabular}

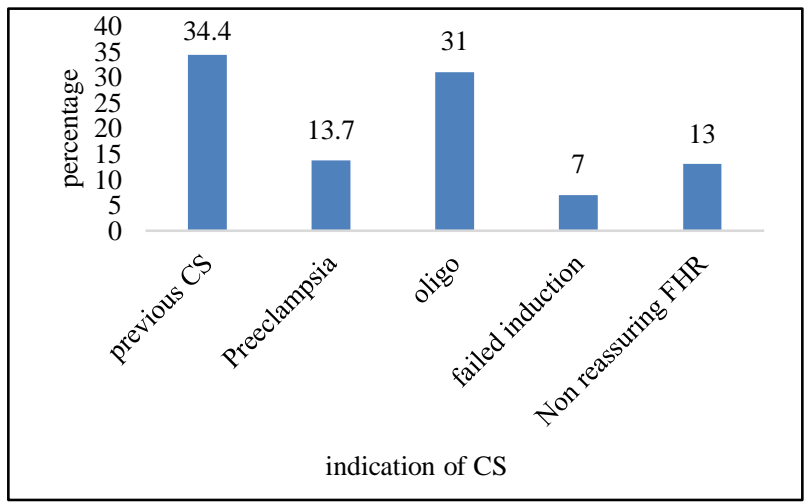

Figure 1: Indication of caesarean section in females with cord around neck.

The indications for caesarean section were previous caesarean (34.4\%), preeclampsia (13.7\%), severe oligohydramnios $(31 \%)$, failed induction $(7 \%)$ and nonreassuring fetal heart rate (13\%) (Figure 1). Out of the 100 babies, 9 babies had APGAR $<7$ at $5 \mathrm{~min}$ and were admitted in NICU due to meconium aspiration, preterm and preclampsia in mothers. Also the number of NICU admissions were almost equal in vaginal and caesarean section (Tables 5 and 6).

Table 5: Distribution of NICU admissions according to mode of delivery.

\begin{tabular}{|llll|}
\hline $\begin{array}{l}\text { Mode of } \\
\text { delivery }\end{array}$ & $\begin{array}{l}\text { NICU } \\
\text { admissions }\end{array}$ \\
\hline Vaginal & 71 & 6 & $8.4 \%$ \\
\hline Caesarean & 29 & 3 & $10.3 \%$ \\
\hline Total & & 9 & \\
\hline
\end{tabular}

Table 6: Indications for NICU admission.

\begin{tabular}{|l|l|}
\hline Meconium aspiration & $\mathbf{3 3 . 3 \%}$ \\
\hline Pre term & $44 \%$ \\
\hline Pre eclamptic mothers & $22 \%$ \\
\hline
\end{tabular}

\section{DISCUSSION}

In our study incidence of nuchal cord was found more in multigravida (58\%) which simulates the findings in studies of Begum et $\mathrm{al}^{7}$ where the majority of the patients (71 cases) were from the age group of 21-25 years (46.71\%) and number of multipara (93 cases) was more.

In this study incidence of single loop around cord was more than multiple loops in this study as well as study by Joshi et al where single loops were in $12.45 \% .^{8}$ Also in our study cord length increased as number of loops of cord around neck increases which is again similar to study by Joshi et al where length of cord was $50.93 \mathrm{~cm}$ in single loop as compared to $72.33 \mathrm{~cm}$ in cases with four loops. ${ }^{8}$

In our study the rate of caesarean section was not increased due to presence of cord. Effect of cord during delivery is transient which is shown by good APGAR score and less number of NICU admissions in our study and that of Begum et al (5\% babies with low APGAR at 1 minute). ${ }^{7}$

Ashok et al found no statistically significant difference in NICU admissions in cord/without cord groups which was similar to our study. ${ }^{9}$

The present study has several limitations. Firstly, it was conducted with a small sample size in a single institution. Secondly cases with multiple entanglements involving multiple parts of body such as shoulder, upper and lower limbs were excluded.

\section{CONCLUSION}

Cord around neck per se is not an indication of caesarean section. These cases can be delivered vaginally if close monitoring is done during labour preferably by fetal electronic heart rate monitoring.

\section{Funding: No funding sources}

Conflict of interest: None declared

Ethical approval: The study was approved by the Institutional Ethics Committee

\section{REFERENCES}

1. Moldenhauer JS. Abnormal Position and Presentation of the Fetus. Merck Manual. Available from: https://www.msdmanuals.com/en-in/home/women-shealth-issues/complications-of-labor-anddelivery/abnormal-position-and-presentation-of-thefetus. accessed on 26 December 2017.

2. Peregrine E, O'brien P, Jauniaux E. Ultrasound detection of nuchal cord prior to labor induction and the risk of cesarean section. Ultrasound Obstet Gynecol. 2005;25(2):160-4.

3. Cruikshank DW, Scott JR. Breech, other malpresentations, and umbilical cord complications. In: Cruikshank DW, Scott JR, eds. Danforth's Obstetrics and Gynecology. Philadelphia: Lippincott Williams and Wilkin; 2003:381-395.

4. Collins JH. Nuchal cord type A and type B. Am J Obstet Gynecol. 1997;177:94. 
5. Rumack CM, Wilson SR, Charboneau JW, Levine D eds. Diagnostic Ultrasound, 4th ed. (two-volume set). Philadelphia, PA: Mosby; 2011:2192 pp.

6. Peesay M. Cord around the neck syndrome. BMC Pregnanc Childbirth. 2012;12(1):11-2.

7. Begum A, Sultana H, Hasan R, Ahmed M. A clinical study of fetal outcome in cases of nuchal cord. J Armed Forces Med Coll Bangladesh. 2011;7(1):25-7.

8. Joshi K, Saxena R, Bhat M, Lomrod Y, Verma K. Incidence of cord around the neck and its effects on labour and neonatal outcome. Adv Hum Biol. 2017;7:15-8

9. Phadol VA, Naik AS, Naik SA. Nuchal cord and perinatal outcome in a rural hospital: a case control study. J Evol Med Dent Sci. 2016;5(53):3531-5.

Cite this article as: Gahlot A, Vyas J, Himani S, Ekta. A study of fetomaternal outcome in singleton pregnancies with cord around neck. Int J Reprod Contracept Obstet Gynecol 2021;10:2725-8. 